石油技術協会誌＼cjkstart第 84 巻＼cjkstart第 3 号（令和元年 5 月） $205 ２ 12$ 頁

Journal of the Japanese Association for Petroleum Technology

Vol. 84, No. 3 (May, 2019) pp. 205 212

\begin{tabular}{l}
\hline 報 \\
Technical Report
\end{tabular}

\title{
新潟地域における温泉水と付随ガスの地球化学
}

\author{
加藤 進 ${ }^{* \dagger} \cdot$ 岩野 裕継 ${ }^{* *}$
}

(Received February 14, 2019 ; accepted April 21, 2019)

\section{Geochemistry of waters and natural gases from hot springs in Niigata Prefecture, Japan}

\author{
Susumu Kato and Hirotsugu Iwano
}

\begin{abstract}
Analytical results of waters and natural gases from seven hot spring wells in Niigata Prefecture are presented. Methane is the dominant hydrocarbon in these spring gases and the gases in the Nishiyama Formation contain about 15\% $\mathrm{CO}_{2}$. The hydrocarbon gases in the Shiiya and Teradomari formations are of thermogenic origin and partly biodegraded. On the other hand, those in the Nishiyama Formation are of microbial origin or mixed origin of microbial and thermogenic similar to production gases from oil and gas fields around the wells.

The spring waters are derived from the fossil seawater. Although those in the Nishiyama Formation are the same as formation waters from oil and gas fields in Niigata, those in the Shiiya and Teradomari formations are distinguished from the formation waters based on $\mathrm{I}^{-} / \mathrm{Cl}^{-}$and $\mathrm{Br}^{-} / \mathrm{Cl}^{-}$ratios.

Lithium contents of the spring waters and the formation waters range from 0.1 to $12.3 \mathrm{mg} / l$ and their $\mathrm{Li}^{+} / \mathrm{Cl}^{-}$ratios are less than 0.001. Temperatures calculated from the $\mathrm{Mg}-\mathrm{Li}$ geothermometer are higher than water temperatures in spring waters, but those are similar to reservoir temperatures in the formation waters.
\end{abstract}

Keywords : spring gas, spring water, formation water, fossil seawater, thermogenic, microbial, lithium, Mg-Li geothermometer

\section{1.はじめに}

日本の温泉はその成因ならびに物質の起源という観点か ら, グリーンタフ型, 海岸温泉型, 火山性型, および有馬 型の 4 つの型に分類され, 水の起源として天水, 海水, 化 石海水 (地層中に残っている堆積時の海水), あるいはマ グマ水などが考えられている（例えば，松葉谷，1981）。

石油探鉱を目的として掘削された坑井から, 温泉水（地 層水）が産出することはよくあることであり, 新潟地域で は瀬波温泉, 月岡温泉, 松之山温泉などがその例である (千谷, 1928 ; 島津, 2001 ; 白石, 2005)。これらのうち, 松之山温泉はジオプレッシャー型の温泉と考えられており (渡部ほか, 2009), 地球化学的によく研究されている（阿 部・酒井, 1983 など)。

新潟地域における温泉の掘削深度は昭和 50 年代には $500 \sim 600 \mathrm{~m}$ 程度であったものが, 昭和 60 年代から平成 のはじめには $1,000 \mathrm{~m}$ 程度になり, 現在では $1,000 \sim 1,500$

\footnotetext{
* (侏)地球科学総合研究所 JGI, Inc.

** 石油資源開発(侏)技術本部技術研究所 JAPEX Research Center, Japan Petroleum Exploration, Co. Ltd.

† Corresponding author : E-Mail : susumukato9@gmail.com
}

$\mathrm{m}$ になっており (白石, 2005), これらの温泉水は化石海 水起源あるいはこれと天水（地表水）の混合したものと推 定される。

北海道では油田塩水と温泉水の化学組成の違いが明らか にされており（太秦・那須, 1960), 新潟地域でも油・ガ 又田の地層水と化石海水起源の温泉水の化学組成や水素 · 酸素同位体組成を比較・検討することは, 堆積物中におけ る海水の続成変質過程を知る上で有効であると考える。特 に, 油・ガス田地層水では寺泊層の分析データが不十分で あり (加藤, 2018), 温泉水がこれを補填する可能性もある。 また, 温泉水に付随するガスは水溶性天然ガスであり, ガ スの組成や起源のデー夕は石油探鉱にも役立つはずである。

本稿では, 幾つかの温泉水と付随ガスの分析結果を報告 するとともに, 既存論文から分析デー夕を引用して, 油・ ガス田地層水と温泉水を地球化学的に比較・検討する。ま た, 資源として, あるいは深部流体の起源を推定する指標 として注目されているリチウムについても報告する。

\section{2. 温泉水と付随ガスの分析結果}

\section{1 試料および分析}

平成 $16 \sim 17$ 年に図 1 に示す 7 温泉 8 坑井から, 温泉水 と付随ガスを採取した。温泉水の化学組成と水素・酸素同 
位体組成，および付随ガスのガス組成と炭素同位体組成を 石油資源開発侏技術研究所において分析した。ガスの分析 結果の一部は加藤ほか（2009）と加藤ほか（2016）で報告

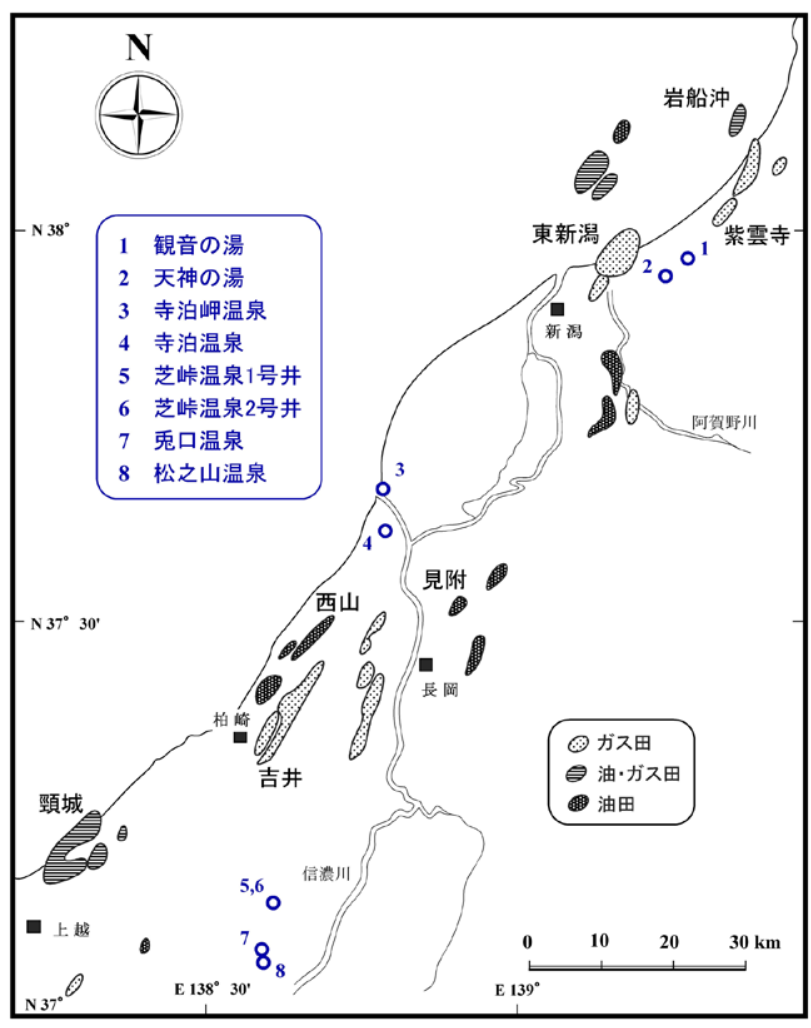

図 1 新潟地域における油・ガス田の分布および温泉 井の位置
している。

\section{2 ガス分析結果}

表 1 に付随ガス（以下，温泉ガス）のガス組成と炭素 同位体組成 $\left(\delta{ }^{13} \mathrm{C}\right)$ の分析結果を示す。温泉ガスは主にメ タン（以下， $\mathrm{C}_{1}$ ) からなる炭化水素がほとんどを占め, 下位の椎谷層（下部鮮新統）・寺泊層（上部中新統）で は $94 \%$ 以上，上位の西山層（上部鮮新統～更新統）では $84 \%$ 程度を占める。エタン $\left(\mathrm{C}_{2}\right)$ は全試料で, プロパン $\left(\mathrm{C}_{3}\right)$ 以上の炭化水素は 4 試料で検出されているが, ウェットネ スは小さく, 芝峠温泉 (以下, 芝峠) 2 号井と松之山温泉（松 之山）で $2 \%$ 以上である。二酸化炭素 $\left(\mathrm{CO}_{2}\right)$ は西山層で は $15 \%$ 程度と非常に多く, 椎谷層や寺泊層では $1 \%$ を超 えるのは寺泊温泉 (寺泊), 松之山, 兔口温泉（兔口）で ある。窒素 $\left(\mathrm{N}_{2}\right)$ は空気補正後で $1 \%$ を超えるのは寺泊岬 温泉 (寺泊岬), 松之山, 天神の湯 (天神) の 3 試料である。

$\mathrm{C}_{1}$ の炭素同位体組成 $\left(\delta^{13} \mathrm{C}_{1}\right)$ からみると, 椎谷層・寺 泊層の温泉ガスは熱分解起源ガス（以下, 熱分解ガス）で あり，西山層の温泉ガスは微生物起源ガス（微生物ガス） あるいは微生物ガスと熱分解ガスの混合からなる（図 2)。

$\delta^{13} \mathrm{C}_{2}$ や $\delta{ }^{13} \mathrm{C}_{3}$ の值を見ると（表 1 ), ケロジェンの $\delta{ }^{13} \mathrm{C}$ 值（例えばー $20 \%$; 重川，1985）よりも重いものや $\mathrm{CO}_{2}$ の $\delta^{13} \mathrm{C}$ 值がプラスのものがあり, これらは微生物分解 (biodegradation) を受けていることを示唆している。

\section{3 水分析結果}

松之山を除く 6 温泉 7 坑井から採取した温泉水の化学組 成および水素・酸素の同位体組成 $\left(\delta \mathrm{D}, \quad \delta^{18} \mathrm{O}\right)$ の分析結 果を表 2 に示す。この表には既存文献や温泉分析書から引 用した温泉水および西山油田と頸城油・ガス田地層水の分

表 1 付随ガスのガス組成と炭素同位体組成

\begin{tabular}{|c|c|c|c|c|c|c|c|c|c|c|c|c|c|c|c|c|}
\hline \multirow{2}{*}{ No. } & \multirow{2}{*}{\multicolumn{2}{|c|}{ 温泉名 }} & \multirow{2}{*}{ 産出層 } & \multicolumn{4}{|c|}{ ガス分析值 } & \multicolumn{3}{|c|}{ (vol\%) } & \multirow{2}{*}{$\begin{array}{c}\text { ウエット祌 } \\
(\%)\end{array}$} & \multirow{2}{*}{$\begin{array}{c}\mathrm{C}_{1} / \\
\left(\mathrm{C}_{2}+\mathrm{C}_{3}\right)\end{array}$} & \multicolumn{4}{|c|}{$\delta^{13} \mathrm{C} \quad(\%)$} \\
\hline & & & & $\mathrm{O}_{2}$ & $\mathrm{~N}_{2}$ & $\mathrm{C}_{1}$ & $\mathrm{C}_{2}$ & $\mathrm{C}_{3}$ & $\mathrm{C}_{4+}$ & $\mathrm{CO}_{2}$ & & & $\mathrm{C}_{1}$ & $\mathrm{C}_{2}$ & $\mathrm{C}_{3}$ & $\mathrm{CO}_{2}$ \\
\hline \multirow[t]{2}{*}{1} & \multirow{2}{*}{\multicolumn{2}{|c|}{ 観音の湯 }} & 西山層 & 1.09 & 3.93 & 80.20 & 0.05 & 0.01 & & 14.71 & 0.07 & 1,337 & -56.9 & -37.5 & -25.9 & -3.8 \\
\hline & & & & & & 84.43 & 0.05 & 0.01 & & 15.49 & & & & & & \\
\hline \multirow[t]{2}{*}{2} & \multirow{2}{*}{\multicolumn{2}{|c|}{ 天神の湯 }} & 西山層 & 1.78 & 8.13 & 76.93 & 0.02 & & & 13.14 & 0.03 & 3,847 & -64.8 & -39.0 & & -7.0 \\
\hline & & & & & 1.64 & 83.99 & 0.02 & & & 14.35 & & & & & & \\
\hline \multirow[t]{2}{*}{3} & \multirow{2}{*}{\multicolumn{2}{|c|}{ 寺泊岬温泉 }} & 寺泊層 & 1.40 & 8.12 & 90.29 & 0.07 & 0.01 & & 0.11 & 0.09 & 1,129 & -37.4 & -14.6 & -28.3 & -8.7 \\
\hline & & & & & 3.11 & 96.69 & 0.08 & 0.01 & & 0.11 & & & & & & \\
\hline \multirow[t]{2}{*}{4} & \multirow{2}{*}{\multicolumn{2}{|c|}{ 寺泊温泉 }} & 寺泊層 & 0.07 & 0.85 & 93.33 & 0.14 & & & 5.61 & 0.15 & 667 & -39.9 & -22.9 & & 18.4 \\
\hline & & & & & 0.59 & 96.64 & 0.14 & & & 5.63 & & & & & & \\
\hline \multirow[t]{2}{*}{5} & \multirow[t]{4}{*}{ 芝峠温泉 } & 1 号井 & 椎谷層 & 0.25 & 1.72 & 96.64 & 0.71 & & & 0.68 & 0.73 & 136 & -36.4 & -27.3 & & \\
\hline & & & & & 0.82 & 97.77 & 0.72 & & & 0.69 & & & & & & \\
\hline \multirow[t]{2}{*}{6} & & 2 号井 & 椎谷層 & 2.00 & 7.64 & 87.96 & 1.94 & 0.06 & 0.09 & 0.30 & 2.32 & 44 & -36.2 & -25.1 & & \\
\hline & & & & & 0.35 & 97.01 & 2.14 & 0.07 & 0.10 & 0.33 & & & & & & \\
\hline 7 & \multirow{2}{*}{\multicolumn{2}{|c|}{ 兔口温泉 }} & 寺泊層 & 1.33 & 4.63 & 92.29 & 0.05 & & & 1.69 & 0.05 & 1,846 & -33.3 & & & 21.4 \\
\hline & & & & & & 98.15 & 0.05 & & & 1.80 & & & & & & \\
\hline \multirow[t]{2}{*}{8} & \multirow{2}{*}{\multicolumn{2}{|c|}{ 松之山温泉 }} & 寺泊層 & 0.99 & 5.29 & 83.58 & 4.65 & 0.76 & 0.98 & 3.76 & 7.10 & 15 & -34.3 & -22.9 & -17.5 & 8.6 \\
\hline & & & & & 1.75 & 87.61 & 4.87 & 0.80 & 1.03 & 3.94 & & & & & & \\
\hline
\end{tabular}


析值も示す。

分析した温泉水の $\delta \mathrm{D}$ は $-17 \sim-7 \%, \quad{ }^{18} \mathrm{O}$ は $-3.7 \sim$ $1.0 \%$ であり,$\delta \mathrm{D}$ の変化は小さく， $\delta{ }^{18} \mathrm{O}$ はかなり変化し ている。図 3 に $\delta \mathrm{D}-\delta^{18} \mathrm{O}$ プロットを示す。すべての試料 が新潟地域の油・ガス田地層水（以下，新潟地層水：加藤, 2018）の範囲に入っている。 $\delta \mathrm{D}$ のデータがない温泉水の

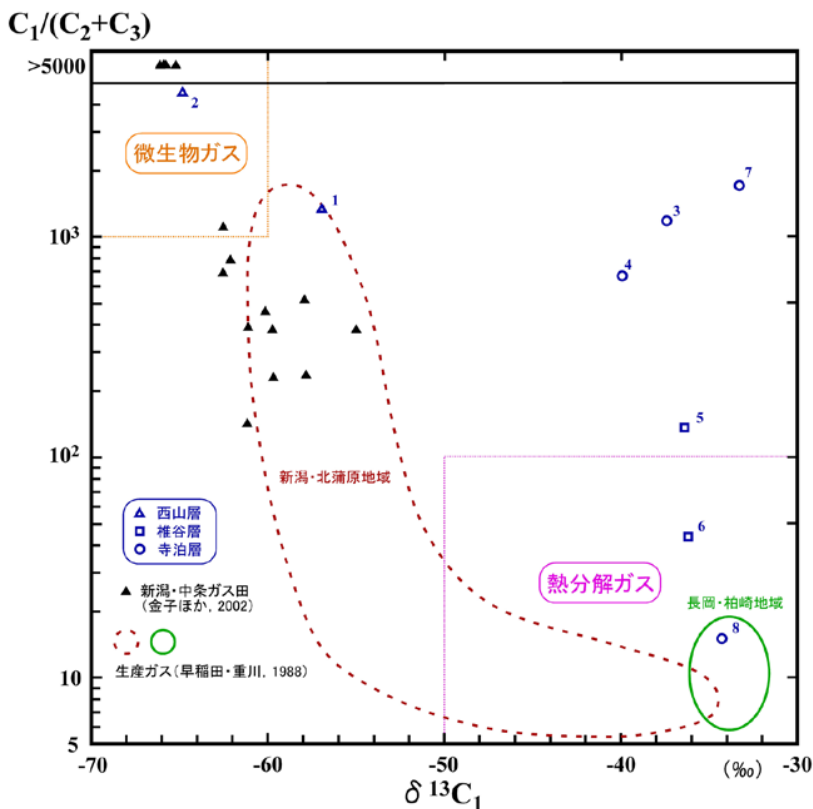

図 2 メタンの起源 $\left(\mathrm{C}_{1} /\left(\mathrm{C}_{2}+\mathrm{C}_{3}\right)-\delta{ }^{13} \mathrm{C}_{1}\right.$ プロット $)$ 数字は図 1 と同じ $\delta^{18} \mathrm{O}$ は $-3.2 \sim-0.5 \%$ であり, 前述の範囲内に入る。一方, 松之山の温泉水は $\delta \mathrm{D}$ が $-29 \sim-20 \%$ と他の温泉水より も明らかに小さく (軽く), $\quad \delta^{18} \mathrm{O}$ は $0.7 \sim 1.4 \%$ とやや大 きい (重い)。これらの温泉水は新潟地域の天水の $\delta \mathrm{D}$ と $\delta{ }^{18} \mathrm{O}$ (Mizota and Kusakabe, 1994 ; 薮崎, 2016）とは明ら かに異なっており，海水（ $\delta \mathrm{D}=0 \%, \quad \delta{ }^{18} \mathrm{O}=0 \%$ \% $)$ に比 較的類似しており, 新潟地層水と同様に海水を起源として いると考えられる。このことは, $\delta^{18} \mathrm{O}-\mathrm{Cl}^{-}$プロット(図 4)

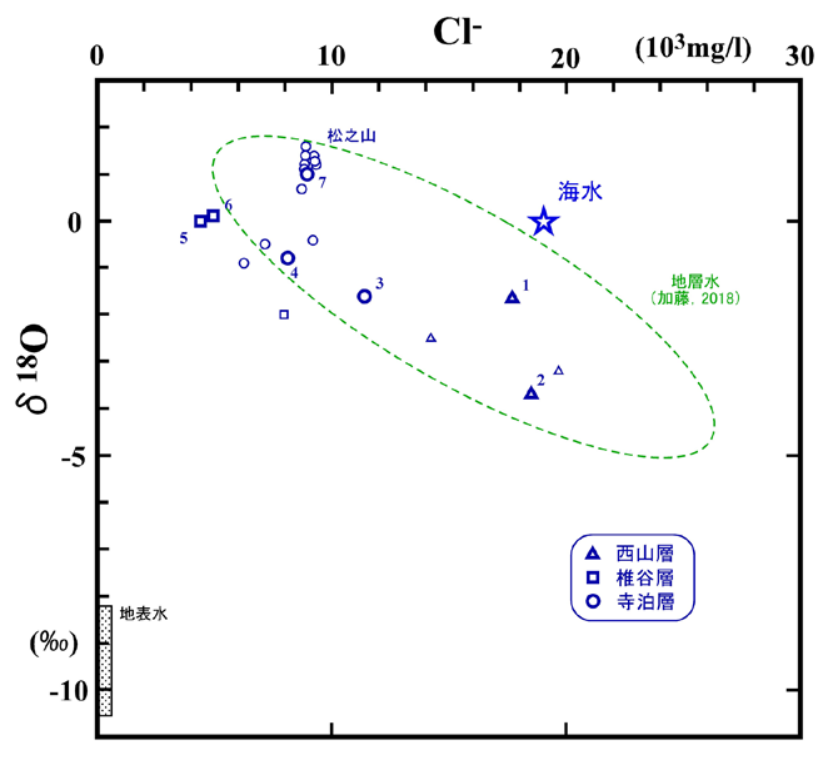

図 $4 \quad \delta^{18} \mathrm{O}-\mathrm{Cl}^{-}$プロット

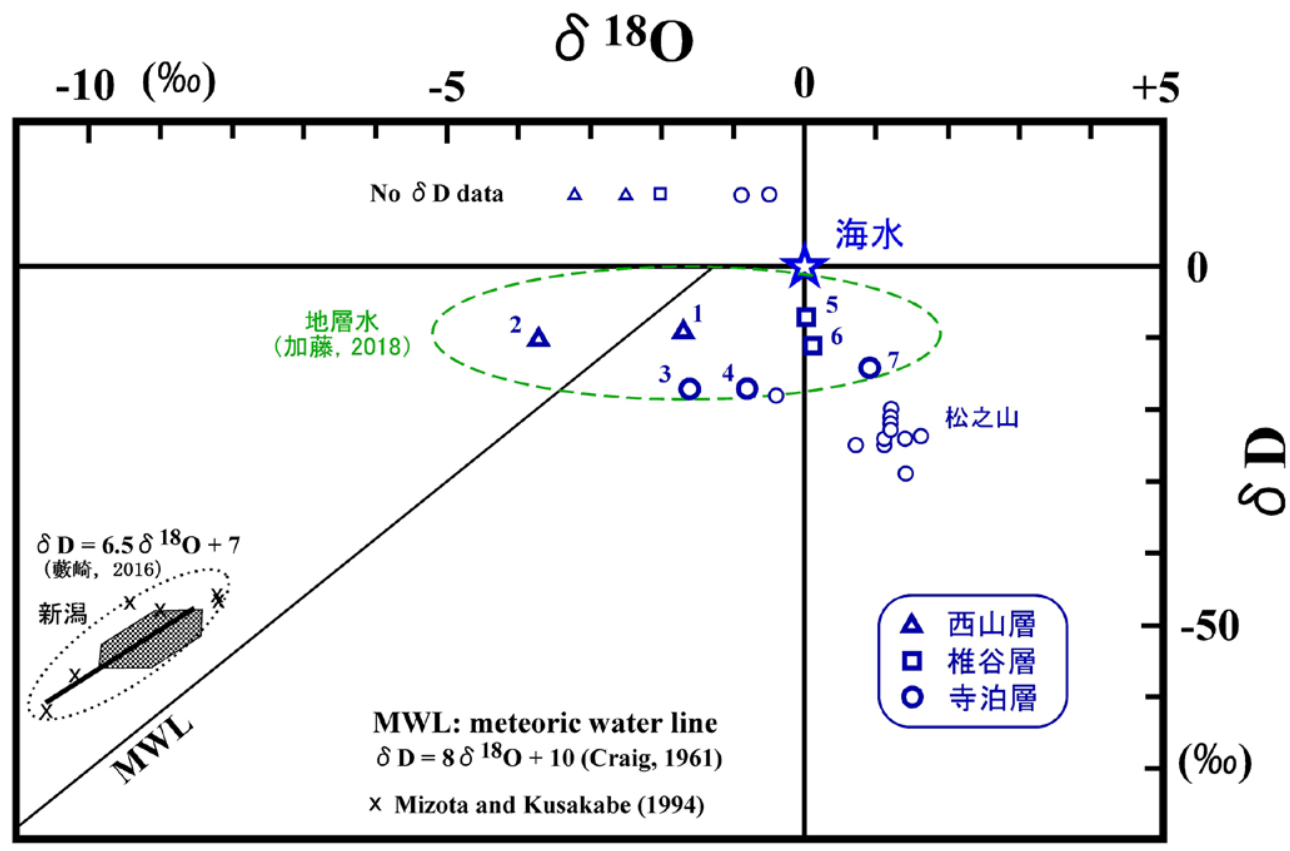

図 $3 \delta \mathrm{D}-\delta^{18} \mathrm{O}$ プロット

$\delta \mathrm{D}$ 值がないデー夕（伊藤ほか，2004）を $\delta \mathrm{D}=0 \%$ の直線より上に示す 
からも支持される。鬼口を含む松之山はやや離れた位置に プロットされるが, 温泉水には $\mathrm{Cl}^{-}$濃度が減少すると $\delta^{18} \mathrm{O}$ が大きくなる傾向が地層水と同様に認められる。

化学組成はかなり変化に富んでおり, $\mathrm{Cl}^{-}$濃度は 4,440 〜 18,500 $\mathrm{mg} / \mathrm{l}$ である（表 2 )。しかしながら，いずれも $\mathrm{Na}^{+}$と $\mathrm{Cl}^{-}$から主になり, 海水と比べて $\mathrm{SO}_{4}{ }^{2-}$ と $\mathrm{Mg}^{2+}$ の 濃度が著しく減少しており, 新潟地層水の特徵（加藤,
2018）に類似している。松之山はいずれの試料も類似した 化学組成を示しており, $\mathrm{Ca}^{2+}$ 濃度が非常に高く, $\mathrm{SO}_{4}{ }^{2-}$ 濃 度も数 $10 \mathrm{mg} / \mathrm{l}$ とやや高いが, 前述の温泉水の特徵を有し ている。

\section{3. 温泉水と地層水の化学組成の比較}

地層水の化学組成は層準によってある傾向をもって変化

表 2 温泉水および油・ガス田地層水の化学組成および水素・酸素同位体組成

\begin{tabular}{|c|c|c|c|c|c|c|c|c|c|c|c|c|c|c|c|c|c|c|c|c|}
\hline \multirow{2}{*}{ No. } & \multirow{2}{*}{\multicolumn{2}{|c|}{ 温泉名 }} & \multirow[t]{2}{*}{ 産出層 } & \multirow{2}{*}{$\begin{array}{l}\text { 水温 } \\
\left({ }^{\circ} \mathrm{C}\right)\end{array}$} & \multirow{2}{*}{$\begin{array}{c}\mathrm{EC} \\
(\mathrm{mS} / \mathrm{cm})\end{array}$} & \multirow[t]{2}{*}{$\mathrm{pH}$} & \multirow{2}{*}{$\begin{array}{c}\mathrm{TDS} \\
(\mathrm{mg} / l)\end{array}$} & \multicolumn{10}{|c|}{ イオン濃度 $\quad(\mathrm{mg} / \mathrm{l})$} & \multicolumn{2}{|c|}{ 同位体組成 $(\%)$} & \multirow[t]{2}{*}{ 文献 } \\
\hline & & & & & & & & $\mathrm{Li}^{+}$ & $\mathrm{Na}^{+}$ & $\mathrm{K}^{+}$ & $\mathrm{Ca}^{2+}$ & $\mathrm{Mg}^{2+}$ & $\mathrm{Cl}^{-}$ & $\mathrm{SO}_{4}^{2-}$ & $\mathrm{HCO}_{3}^{-}$ & $\mathrm{I}^{-}$ & $\mathrm{Br}^{-}$ & $\delta \mathrm{D}$ & $0^{18} 0$ & \\
\hline 1 & 観音の湯 & & 西山層 & 46 & 47.4 & 7.47 & 31,200 & 4.2 & 11,000 & 136 & 394 & 90.1 & 17,700 & ND & 1,000 & 68 & 122 & -9 & -1.7 & \\
\hline 2 & 天神の湯 & & 西山層 & 45 & 48.9 & 7.48 & 33,000 & 1.4 & 10,900 & 470 & 584 & 290 & 18,500 & ND & 1,100 & 65 & 121 & -10 & -3.7 & \\
\hline 3 & 寺泊岬温泉 & & 寺泊層 & 46 & 30.9 & 7.14 & 21,400 & 0.5 & 5,090 & 31.4 & 2,190 & 17.9 & 11,400 & 1.3 & 28 & 3.7 & 38.4 & -17 & -1.6 & \\
\hline 4 & 寺泊温泉 & & 寺泊層 & & 22.1 & 7.90 & 16,000 & 6.6 & 5,920 & 30.7 & 103 & 79.3 & 8,130 & 0.6 & 2,200 & 6.4 & 30.3 & -17 & -0.8 & \\
\hline 5 & 芝峠温泉 & 1 号井 & 椎谷層 & 23 & 13.8 & 7.72 & 8,030 & 0.1 & 2,930 & 12.0 & 107 & 9.3 & 4,440 & 0.0 & 490 & 4.4 & 20.1 & -7 & 0.0 & \\
\hline 6 & & 2 号井 & 椎谷層 & 27 & 14.5 & 7.83 & 9,410 & 0.2 & 2,830 & 12.8 & 433 & 1.8 & 4,900 & 23 & 73 & 8.0 & 22.8 & -11 & 0.1 & \\
\hline 7 & 鬼口温泉 & & 寺泊層 & & 25.8 & 7.67 & 16,800 & 1.2 & 5,910 & 32.1 & 201 & 55.3 & 8,950 & ND & 700 & 4.6 & 33.3 & -14 & 1.0 & \\
\hline \multicolumn{21}{|c|}{8 松之山温泉 } \\
\hline & & 翠の湯 & 寺泊層 & & & & & & 3,505 & 146 & 1,983 & 5.0 & 8,877 & 73 & 87 & & & -23 & 1.2 & 1) \\
\hline & & 鷹の湯 & 寺泊層 & & & & & & 3,674 & 140 & 2,070 & 1.8 & 9,317 & 75 & 61 & & & -21 & 1.2 & 1) \\
\hline & & 鏡の湯 & 寺泊層 & & & & & & 3,662 & 105 & 1,933 & 19 & 9,062 & 69 & 58 & & & -20 & 1.2 & 1) \\
\hline & & 湯坂温泉 & 寺泊層 & & & & & & 3,862 & 107 & 1,816 & 5.9 & 9,376 & 89 & 52 & & & -22 & 1.2 & 1) \\
\hline & & 高橋建設 & & 52 & & 7.2 & & 1.79 & 4,050 & 83 & 1,733 & 34.7 & 8,924 & 52 & 52 & & & -24 & 1.4 & 2) \\
\hline & & 凌雲閣 & & 75 & & 7.5 & & 1.94 & 3,815 & 109 & 1,845 & 34.2 & 8,982 & 93 & 25 & & & -24 & 1.1 & 2) \\
\hline & & 町営 1 & & 86 & & 7.6 & & 2.69 & 3,182 & 167 & 1,887 & 3.0 & 8,720 & 83 & 54 & & & -25 & 0.7 & 2) \\
\hline & & 町営 2 & & 95 & & 7.8 & & 2.13 & 3,850 & 141 & 1,973 & 13.4 & 9,227 & 94 & 47 & & & -29 & 1.4 & 2) \\
\hline & & 鬼口 & & 36 & & 7.3 & & 1.27 & 5,480 & 39 & 193 & 46.3 & 8,895 & 213 & 873 & & & -24 & 1.6 & 2) \\
\hline & 松之山 & & & 75 & & 7.3 & & 1.72 & 3,580 & 116 & 1,870 & 0.2 & 8,828 & 41 & 145 & & & -25 & 1.1 & 3) \\
\hline & 寺泊 & & & 34 & & 8.0 & & 7.34 & 6,610 & 41 & 126 & 90.0 & 9,149 & 0 & 3,004 & & & -18 & -0.4 & 3) \\
\hline & 中条町 & & 西山層 & 84 & 36.1 & 8.2 & & & 9,275 & 106 & 235 & 88.0 & 14,202 & 0.0 & 179 & & & & -2.5 & 4) \\
\hline & 新潟市 & & 西山層 & 50 & 48.1 & 7.5 & & & 10,739 & 355 & 394 & 489 & 19,699 & 0.0 & 598 & & & & -3.2 & 4) \\
\hline & 大潟町 & & 椎谷層 & 19 & 23.7 & 7.6 & & & 5,120 & 21.8 & 147 & 42.7 & 8,001 & 0.0 & 313 & & & & -2.0 & 4) \\
\hline & 吉川町 & & 寺泊層 & 49 & 21.1 & 7.8 & & & 4,893 & 18.0 & 91.0 & 21.7 & 7,170 & 0.0 & 471 & & & & -0.5 & 4) \\
\hline & 安塚町 & & 寺泊層 & 58 & 19.0 & 7.4 & & & 3,262 & 15.5 & 837 & 3.8 & 6,289 & 79 & 47 & & & & -0.9 & 4) \\
\hline & 塩の湯 & N 20-4 & 西山層 & 74 & & & 34,410 & 5.7 & 12,760 & 163 & 316 & 92.9 & 19,400 & & 836 & 85 & 134 & & & 5) \\
\hline & 温泉 & N 22-2 & 西山層 & 76 & & & 33,210 & 6.0 & 11,620 & 156 & 315 & 61.0 & 19,400 & & 882 & 77 & 120 & & & 5) \\
\hline & 糸魚川温泉 & & 七谷層 & 96 & & 7.5 & & 3.5 & 5,200 & 280 & 1,800 & 7.8 & 7,700 & 240 & 21 & 9.5 & 28 & & & 5) \\
\hline \multicolumn{21}{|c|}{ 西山油田 } \\
\hline & & 別山 R52 & 寺泊層 & & & 8.2 & & 1.1 & 4,700 & 47 & 37 & 14 & 6,618 & & & 15 & 62 & & & 6) \\
\hline & & 伊毛 R47 & 寺泊層 & & & & & 2.7 & 6,450 & 65 & 24 & 80 & 11,154 & & & 26 & 109 & & & 6) \\
\hline & & 伊毛 R19 & 寺泊層 & & & & & 4.2 & 6,730 & 44 & 36 & 134 & 11,422 & & & 28 & 112 & & & 6) \\
\hline & & 鎌田 R77 & 椎谷層 & & & 7.4 & & 12.3 & 8,540 & 125 & 343 & 866 & 17,661 & & & 49 & 170 & & & 6) \\
\hline & & 後谷 C55 & 椎谷層 & & & & & 3.5 & 8,240 & 27 & 249 & 323 & 15,742 & & & 38 & 129 & & & 6) \\
\hline & & 長嶺 R78 & 椎谷層 & & & 6.6 & & 7.2 & 7,290 & 92 & 476 & 849 & 14,682 & & & 43 & 125 & & & 6) \\
\hline & & 長嶺 R87 & 椎谷層 & & & 7.5 & & 7.8 & 9,270 & 125 & 770 & 925 & 19,678 & & & 55 & 128 & & & 6) \\
\hline & & 入和田 R6 & 椎谷層 & & & & & 2.0 & 7,350 & 85 & 432 & 115 & 14,179 & & & 37 & 136 & & & 6) \\
\hline & & 滝谷 R13 & 椎谷層 & & & & & 3.4 & 7,540 & 98 & 717 & 238 & 15,675 & & & 37 & 136 & & & 6) \\
\hline & & 刈羽 R103 & 寺泊層 & & & & & 1.9 & 4,830 & 58 & 38 & 44 & 9,709 & & & 20 & 89 & & & 6) \\
\hline & & 湯入 R52 & 寺泊層 & & & & & 1.9 & 3,510 & 39 & 31 & 16 & 7,134 & & & 16 & 69 & & & 6) \\
\hline \multicolumn{21}{|c|}{ 頸城油・ガス田 } \\
\hline & & 黒井 & 寺泊層 & & & 7.80 & & & & & 72 & 31 & 8,795 & 0 & 1,366 & 23 & 48 & & & 7) \\
\hline & 海水 & & & & & 8.20 & & 0.18 & 10,560 & 380 & 400 & 1,270 & 18,980 & 2,650 & 130 & 0.05 & 65 & 0 & 0.0 & 8), 9) \\
\hline
\end{tabular}


している（加藤, 2018）ので, 温泉水でも産出区間の層準 を区別することにする（表 2)。また, 温泉水で通常分析 が行われる成分は地層水の場合と少し異なっている(表2)。 北海道で油田塩水と温泉水で違いが明瞭であり（太秦・

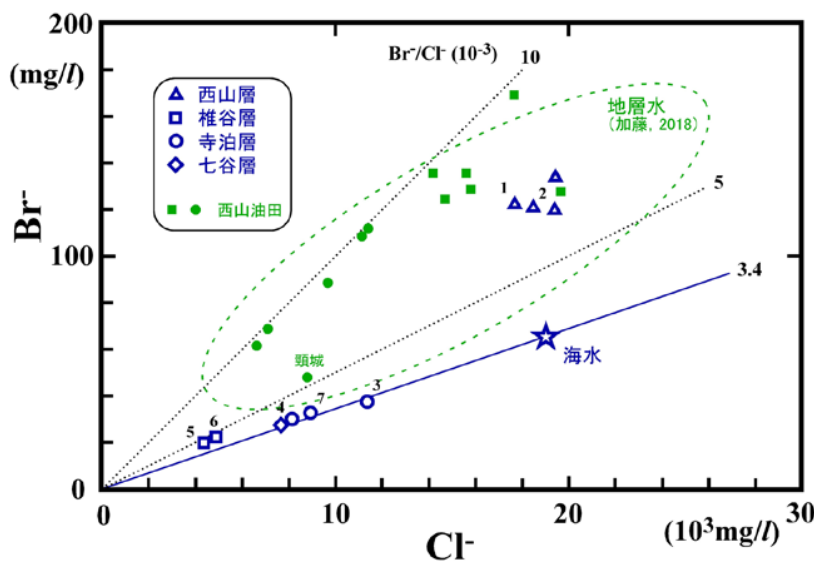

図 $5 \mathrm{Br}^{-}-\mathrm{Cl}^{-}$プロット

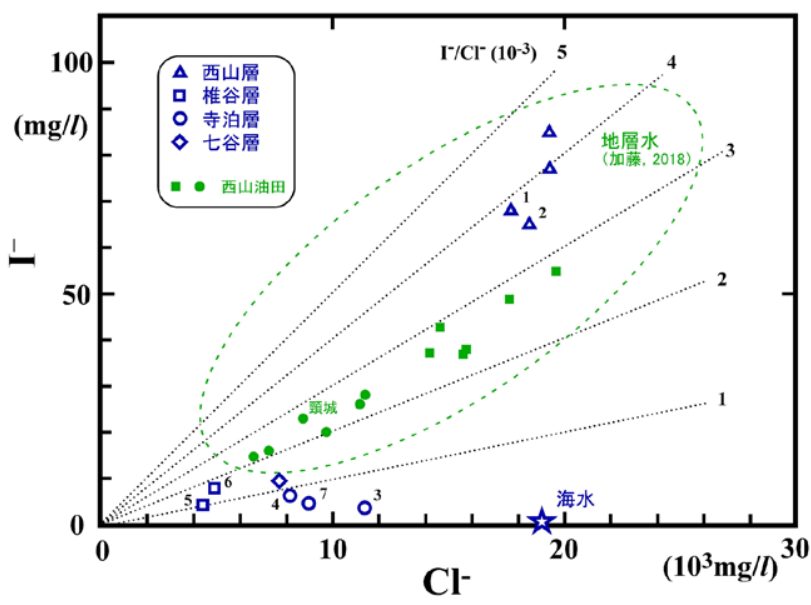

図 $6 \mathrm{I}^{-}-\mathrm{Cl}^{-}$プロット

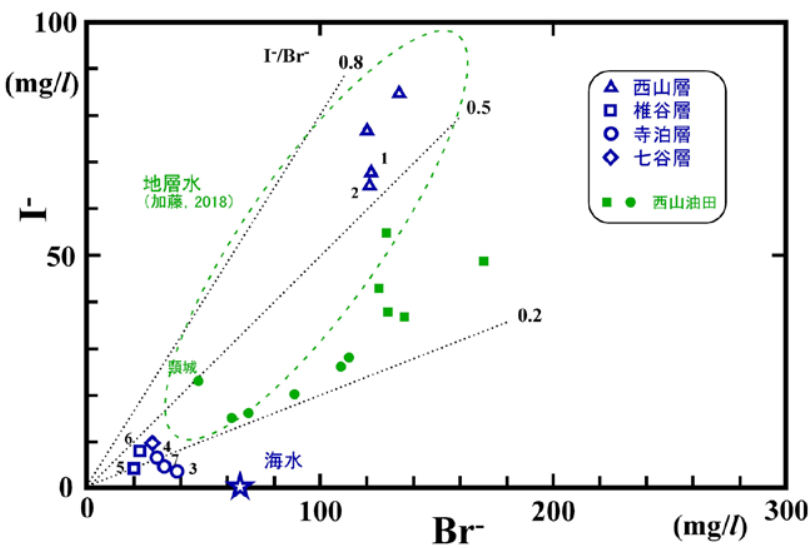

図 $7 \quad \mathrm{I}^{-}-\mathrm{Br}^{-}$プロット
那須, 1960), 水が生成した時の情報をある程度提供して くれる $\mathrm{Br}^{-} / \mathrm{Cl}^{-}$比（上村, 1988）について最初に検討する。 $\mathrm{Br}^{-}$と $\mathrm{Cl}^{-}$のプロットを図 5 に示す。西山層のものを除けば, 温泉水は海水の $\mathrm{Br}^{-} / \mathrm{Cl}^{-}$比 $\left(3.4 \times 10^{-3}\right)$ とほぼ同じであ るのに対し，同層準の西山油田や頸城油・ガス田の地層水 では $\mathrm{Br}^{-} / \mathrm{Cl}^{-}$比が大きく $\left(5 \sim 10 \times 10^{-3}\right)$, 海水起源と生 物 (有機物) 起源の $\mathrm{Br}^{-}$が混合していると考えられる (上 村, 1988)。西山層の温泉水は新潟地層水の範囲内にある。

有機物に由来する I'についてみると, 温泉水では濃度 は $3.7 \sim 68 \mathrm{mg} / l$ であり, すべて海水の值 $(0.05 \mathrm{mg} / l)$ よ りも高いが, 西山層を除くと $10 \mathrm{mg} / l$ 未満と比較的低い。

$\mathrm{I}^{-} / \mathrm{Cl}^{-}$比も椎谷層・寺泊層の温泉水では $1 \times 10^{-3}$ 前後で あるが，西山油田や頸城油・ガス田の地層水では $2 \sim 3 \times$ $10^{-3}$ である（図 6)。一方, 西山層の温泉水ではこの比が $4 \times 10^{-3}$ 前後であり, 新潟地層水の範囲内にある。

西山層を除くと温泉水の $\mathrm{I}^{-} / \mathrm{Br}^{-}$比は 0.5 未満であり, $\mathrm{Br}^{-}$濃度も海水の值 $(65 \mathrm{mg} / l)$ より低い（図 7)。新潟地 層水の $\mathrm{I}^{-} / \mathrm{Br}^{-}$比は多くが $0.2 \sim 0.8$ の範囲にあり, 西山層 の温泉水の $\mathrm{I}^{-} / \mathrm{Br}^{-}$比も 0.5 以上でその範囲内に入る。西山

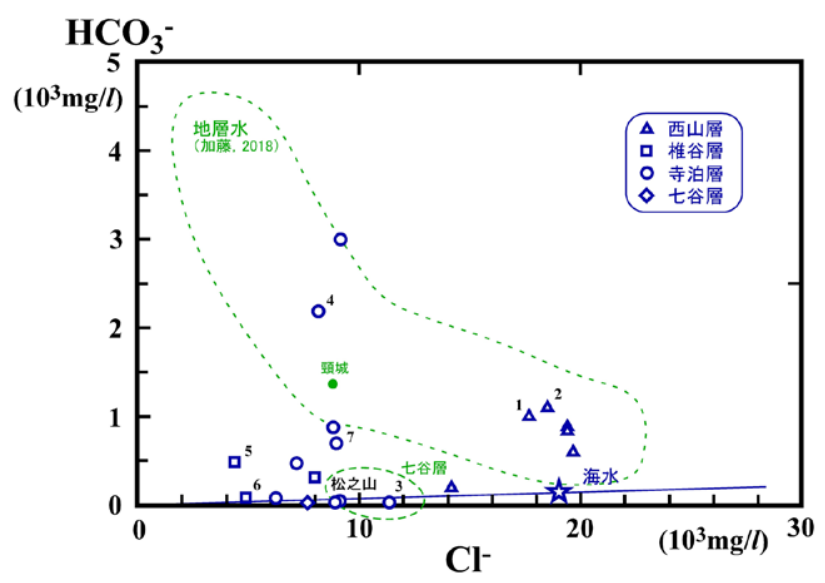

図 $8 \mathrm{HCO}_{3}^{-}-\mathrm{Cl}^{-}$プロット

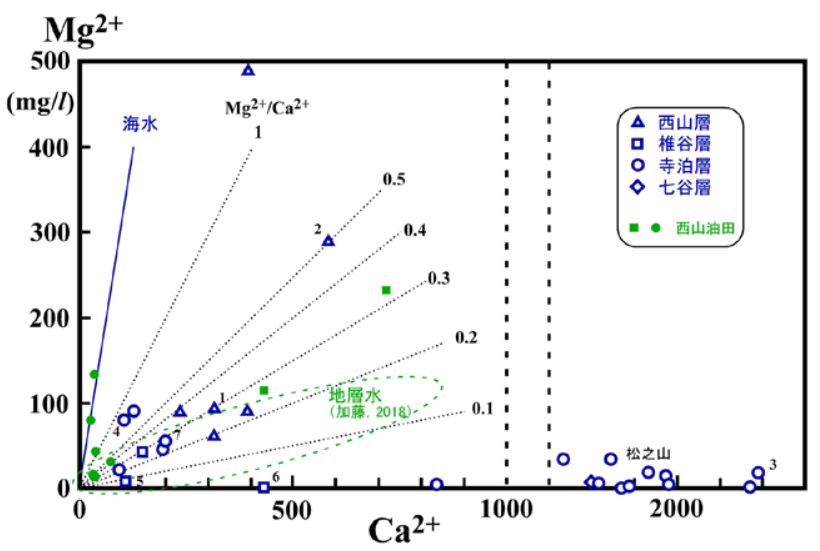

図 $9 \mathrm{Mg}^{2+}-\mathrm{Ca}^{2+}$ プロット

J. Japanese Assoc. Petrol. Technol. Vol. 84, No. 3 (2019) 
油田の地層水では, $\mathrm{I}^{-} / \mathrm{Br}^{-}$比は 0.5 未満であるが，寺泊層 よりも椎谷層でこの比は大きい。

同様に有機物に由来する $\mathrm{HCO}_{3}{ }^{-}$（工藤，1983； Maekawa et al., 2006) 濃度は $28 \sim 2,200 \mathrm{mg} / l$ (文献值 を入れれば, $21 〜 3,004 \mathrm{mg} / l)$ と大きく変化しており， $\mathrm{Ca}^{2+}$ 濃度が高いもので低い傾向が認められる（表 2)。 $\mathrm{HCO}_{3}{ }^{-}-\mathrm{Cl}^{-}$プロット（図 8）では, 西山層や寺泊の温泉 水は新潟地層水の範囲内にあるが，その他の温泉水はその 範囲の下方 $\left(\mathrm{HCO}_{3}^{-}\right.$濃度が低い) に位置しており，松之山 や寺泊岬の温泉水は七谷層（火山岩類）の地層水（加藤, 2018）とほぼ同じ位置にプロットされる。

$\mathrm{Mg}^{2+}$ 濃度は西山層の一部を除き $100 \mathrm{mg} / l$ 未満であり, $\mathrm{Mg}^{2+} / \mathrm{Ca}^{2+}$ 比は海水よりも小さく，西山層の一部を除きく 1 であるが，新潟地層水（西山油田を除く）よりも大きい ものがある（図 9)。一方， $\mathrm{Ca}^{2+}$ 濃度が高い松之山などは 七谷層の地層水に類似している。

\section{4. 温泉水および地層水のリチウム濃度}

リチウム（Li） は最も軽いアルカリ金属元素であり， 次世代電池にとって代替困難な必須の元素である（村 上，2010）。流体相に非常に分配されやすい元素の 1 つで あり，高温を経験した深部流体は低温しか経験していな い表層水に比べ著しく Li に富む（西尾，2013）。温泉水の $\mathrm{Li}^{+}$濃度は海水（0.181 mg/l ; 村上， 2010）より通常高<, Takamatsu et al. (1986) が報告した国内 30 の温泉水の $\mathrm{Li}^{+}$ 濃度は $0.15 \sim 62.2 \mathrm{mg} / l$ であり，特に有馬温泉や鹿塩温泉 で高い $\mathrm{Li}^{+}$濃度を示している。

新潟地域の温泉水や西山油田の地層水の $\mathrm{Li}^{+}$濃度は 0.1 〜 $12.3 \mathrm{mg} / l$ であり（表 2 ），西山油田の地層水や寺泊およ び西山層の温泉水で $5 \mathrm{mg} / \mathrm{l}$ 以上と高い。高橋ほか (2011) のデータを加えた $\mathrm{Li}^{+}-\mathrm{Cl}^{-}$プロットを図 10 に示す。新潟 地域の温泉水と地層水では, $\mathrm{Li}^{+} / \mathrm{Cl}^{-}$比はいずれも 0.001 未満（大部分は 0.0005 未満）であり，両者の間に違いは 認められない。しかし，西山油田の地層水には， $\mathrm{Cl}^{-}$濃度 が増えると $\mathrm{Li}^{+}$濃度も増加する傾向が認められ，椎谷層の

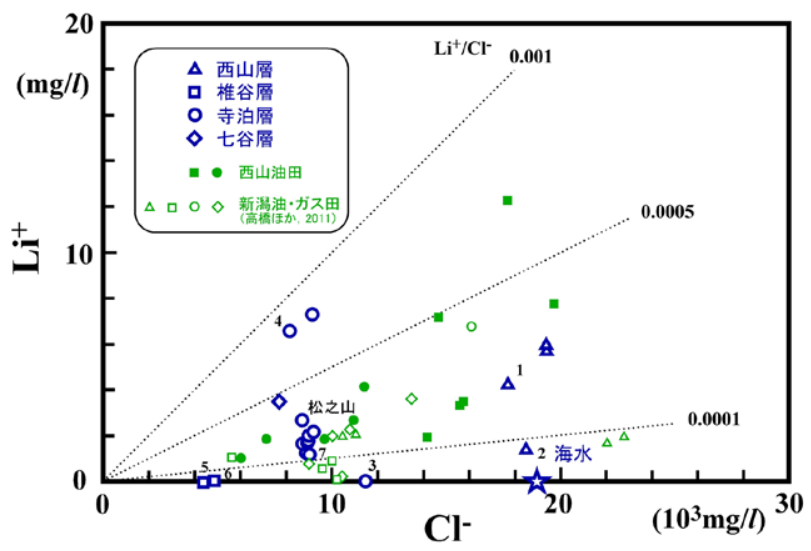

図 $10 \mathrm{Li}^{+}-\mathrm{Cl}^{-}$プロット
地層水で $\mathrm{Li}^{+}$濃度が高い傾向がある。

5. 考察

温泉ガスは主に $\mathrm{C}_{1}$ からなる炭化水素が主体であるが, $\mathrm{C}_{1}$ の起源（ $\delta^{13} \mathrm{C}_{1}$ 值） は西山層と椎谷層・寺泊層で異なっ ており，後者は熱分解ガスからなるが，前者は微生物ガス

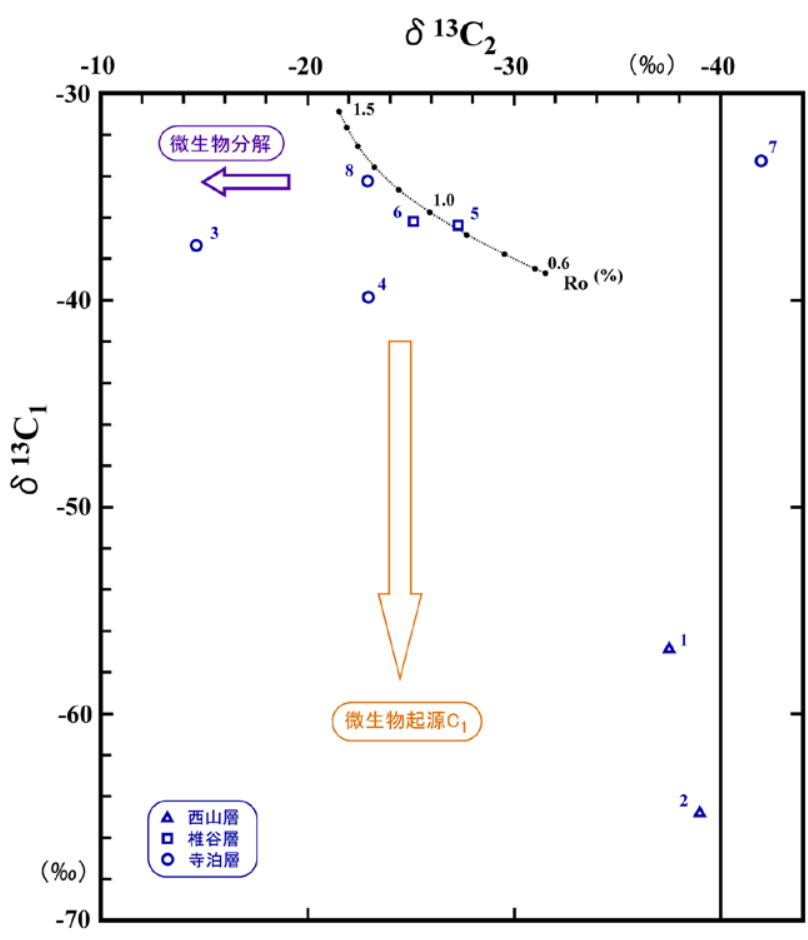

図 $11 \delta{ }^{13} \mathrm{C}_{1}-\delta{ }^{13} \mathrm{C}_{2}$ プロット Ro ラインは早稲田ほか（2002）に基づく

油・ガス層温度/水温 $(\mathrm{B})$

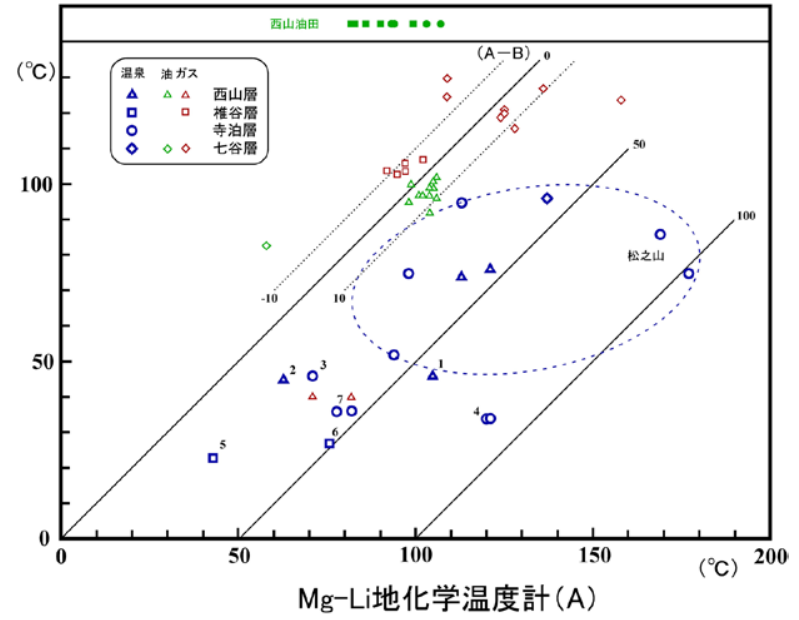

図 12 油・ガス層温度（水温）と $\mathrm{Mg}-\mathrm{Li}$ 地化学温度 計から求めた温度の比較

西山油田については油層温度が不明のため, $\mathrm{Mg}-\mathrm{Li}$ 地化学温 度計から求めた温度のみを示す 
が主体である。油・ガス田の生産ガス（以下生産ガス）の $\delta{ }^{13} \mathrm{C}_{1}$ 值は新潟・北蒲原地域と長岡・柏崎地域で異なって おり（早稲田・重川，1988；図 2)，西山層の観音の湯（観 音）と天神は新潟・北蒲原地域の範囲内にあり, 生産ガス や水溶性ガスの $\delta{ }^{13} \mathrm{C}_{1}$ 值と調和している。一方，その他の 温泉ガスは長岡・柏崎地域の生産ガスと同様かやや軽い $\delta^{13} \mathrm{C}_{1}$ 值を示す。したがって，温泉ガスと生産ガスの $\mathrm{C}_{1}$ の起源は同じであると考えられる。

$\delta^{13} \mathrm{C}_{1}-\delta{ }^{13} \mathrm{C}_{2}$ プロットを図 11 に示す。ガスの熟成度を 示す Ro ライン（早稲田ほか，2002） から $\delta^{13} \mathrm{C}_{2}$ 值が大き く外れる寺泊岬は $\mathrm{C}_{2}$ が微生物分解を受けていると考えら れる。一方， $\delta^{13} \mathrm{C}_{1}$ 值が軽い方にシフトしている観音や天 神は微生物起源の $\mathrm{C}_{1}$ や $\mathrm{C}_{2}$ が混入していると推定される。 芝峠の熱分解ガスの熟成度は Ro 換算で $1 \%$ 程度であり, 松之山のそれは微生物分解の影響を受けていることを考慮 すると，これと同程度かやや高いと推定される。これらの 近傍に分布する室野や蒲生の泥火山やその周辺から採取さ れたガスの熟成度も Ro 換算で $1.0 \sim 1.1 \%$ ある（加藤ほ か, 2009)。

今回報告した温泉水はいずれも化石海水起源と考えられ る(図 3，4）。しかしながら，その化学組成は西山層と椎 谷層・寺泊層とで違いが認められる。椎谷層・寺泊層の温

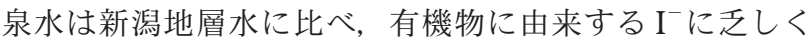
$\left(10 \mathrm{mg} / l\right.$ 未満), $\mathrm{I}^{-} / \mathrm{Cl}^{-}$比は $1 \times 10^{-3}$ 程度である（図 6)。 また, $\mathrm{Br}^{-}$濃度は海水の值よりも低く, $\mathrm{Br}^{-} / \mathrm{Cl}^{-}$比は海水 と同程度であり, 新潟地層水よりも小さい（図 5)。一方, 西山層の温泉水は新潟地層水と区別できない。寺泊層は 油・熱分解ガスの根源岩層準であり（例えば，平井ほか, 1995)，温泉水での低い $\mathrm{I}^{-} / \mathrm{Cl}^{-}$比や $\mathrm{Br}^{-} / \mathrm{Cl}^{-}$比は根源岩の 有機物量の違いを反映しているかも知れない。

Mg-Li 地化学温度計（Kharaka and Mariner, 1989）はメ キシコ湾堆積盆ではいろいろな地化学温度計のうち最も

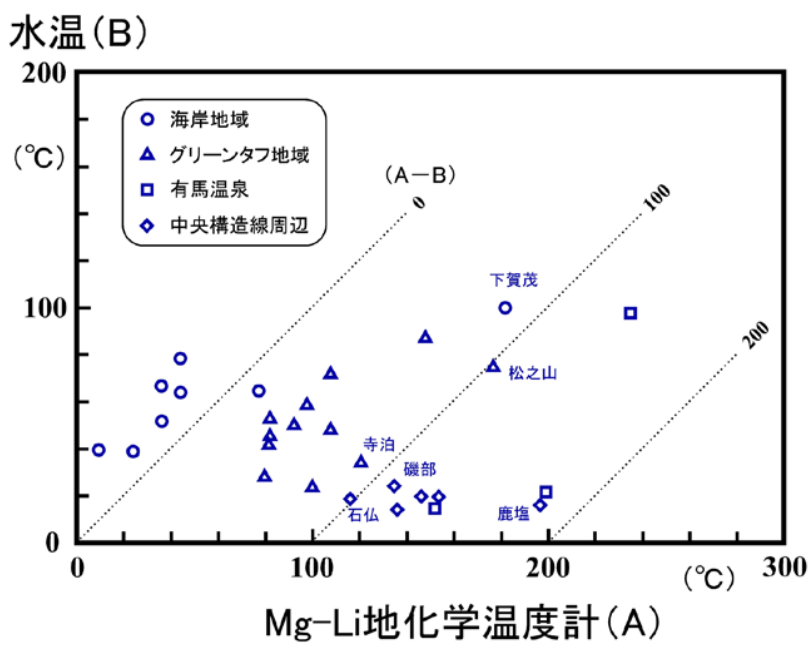

図 13 温泉水における水温と Mg-Li 地化学温度計から 求めた温度の比較
有用であり, 貯留層温度と良く相関している（Land and Macpherson, 1992)。図 12 には, 高橋ほか（2011）や石油 資源開発(株)の社内デー夕も加えて, $\mathrm{Mg}-\mathrm{Li}$ 地化学温度計 (以 下, Mg-Li 温度計) から計算した温度 $\left(t=2200 /\left(\log \left(\mathrm{Mg}^{1 / 2} /\right.\right.\right.$ $\mathrm{Li})+5.47)-273)$ と油・ガス層温度（温泉井では水温） との比較を示す。西山油田については, 油層温度が不明で あるが，採水深度は 370 ～1,573 m である（野口・森崎, 1971)。Mg-Li 温度計から計算した温度は $82 \sim 107^{\circ} \mathrm{C}$ であ り（図 12）, 新潟地域の油・ガス層の平均地温勾配（約 $4^{\circ} \mathrm{C}$ $/ 100 \mathrm{~m}$ ）の温度（加藤，2018） と比較するとより高く, その違いは浅い深度の油層ほど大きい傾向が認められる。 油・ガス層では, 両者の温度が比較的類似している（ほぼ $\pm 10^{\circ} \mathrm{C}$ の範囲）のに対し, 温泉井では $\mathrm{Mg}-\mathrm{Li}$ 温度計の温 度が明らかに高く, 特に松之山（バラツキが大きい）や寺 泊で高い。水温は地表での温度であり, 地下の貯留層での 温度よりもある程度は低くなるが, 通常数 $10^{\circ} \mathrm{C}$ 低くな ることはない。

Takamatsu et al. (1986) のデー夕を用いて, 温泉水につ いて同様のプロットを作成した（図 13）。この図では，4 つのグループは基本的には Takamatsu et al. (1986) に従つ ているが，石仏と磯部を中央構造線周辺に加えている。海 岸地域では，水温の方が $\mathrm{Mg}-\mathrm{Li}$ 温度計よりも高い傾向が あり，それ以外はいずれも $\mathrm{Mg}-\mathrm{Li}$ 温度計の方が高く，そ の温度差はグリーンタフ地域, 中央構造線周辺, 有馬温泉 の順に大きくなっている。また，松之山と寺泊はグリーン 夕フ地域で最も温度差が大きい。有馬温泉や石仏, 鹿塩は 有馬型温泉に分類され（例えば，松葉谷，2009）, $\mathrm{Li}^{+} / \mathrm{Cl}^{-}$ 比が 0.001 より大きいことから, スラブ起源水（マグマ水 も広義のスラブ起源水）が混入していると考えられている （風早, 2014）。一方, 新潟地層水や温泉水は $\mathrm{Li}^{+} / \mathrm{Cl}^{-}$比が 0.001 より 小さく, スラブ起源水の混入はないと判断される。

松之山では, 温泉水は地下 $3,000 ４, 000 \mathrm{~m}$ にある根源 的貯留層から断層や亀裂を通して上昇してきたと考えられ ている（渡部ほか，2009）。また，寺泊周辺では，七谷層 中に厚いドレライトが確認されている（加藤ほか，2016） ことから, 寺泊の温泉水にはマグマが関連している可能性 がある。

油・ガス層において, Mg-Li 温度計から計算した温度と 油・ガス層温度が近似していることは地層水がほぼその場 所で形成された（ほとんど移動していない）ことを示唆し ており，油・ガスがより深部から移動してきたのとは明ら かに異なっている。

\section{6. まとめ}

7 温泉 8 坑井から採取した温泉水と付随ガスの分析結果 を報告した。温泉ガスは $\mathrm{C}_{1}$ から主になり，西山層のもの は $\mathrm{CO}_{2}$ を $15 \%$ 程度含んでいる。椎谷層・寺泊層の温泉ガ スは熱分解ガスからなり, 一部は微生物分解を受けている。 一方, 西山層の温泉ガスは周辺の生産ガスと同様に微生物 ガスが主である。

温泉水はいずれも化石海水起源であり, 椎谷層・寺泊層 
の化学組成は $\mathrm{I}^{-} / \mathrm{Cl}^{-}$比や $\mathrm{Br}^{-} / \mathrm{Cl}^{-}$比から新潟地層水と区 別可能であるが, 西山層のそれは新潟地層水に類似して いる。

温泉水と新潟地層水の $\mathrm{Li}^{+}$濃度は $0.1 \sim 12.3 \mathrm{mg} / l$ であり, $\mathrm{Li}^{+} / \mathrm{Cl}^{-}$比はすべて 0.001 未満である。 $\mathrm{Mg}-\mathrm{Li}$ 温度計から 計算した温度は, 温泉水では水温よりも高く, $100^{\circ} \mathrm{C}$ 程度 異なることもあるが，新潟地層水では油・ガス層温度に近 似している。

\section{引用 文 献}

阿部修治・酒井 均, 1983 ：中部日本内陸地帯の諸温 泉・鉱泉水の安定同位体組成. 温泉工学会誌, 18(1), $37-50$.

馬場維男, 1966 ：八橋油田VIII層および頸城油田 I 層の水圧 入テストの問題点. 石技誌，31(6), 280-288.

千谷好之助, 1928: 本邦油田に於ける温泉 (一). 地学雑誌, 40 (477), 626-636.

Craig, H., 1961 : Isotopic variation in meteoric waters. Science, $133,1702-1703$.

平井明夫 ・ 岡田静子 - 若松屋伸一 ・宮本泰行 ・八戸和巳,

1995 : 有機地球化学的にみた新潟地域における原油とそ の根源岩の関係．石技誌，60(1)，87-97.

伊藤俊方・小松原岳史・佐藤 修, 2004：北部フォッサマ グナ地域における深層地下水の水質特性. 応用地質, 45 (1), 22-30.

上村京子 - 高松信樹 - 今橋正征, 1988 : 食塩泉の $\mathrm{Br} / \mathrm{Cl}$ 比 について. 温泉科学, 38, 111-119.

金子信行・前川竜男・猪狩俊一郎，2002：アーケアによる メタンの生成と間隙水への濃集機構. 石技誌, 67 (1), 97-110.

加藤 進, 2018 : 新潟地域における油・ガス田地層水の地 球化学. 石技誌, 83(4), 257-266.

加藤 進・岩野裕継・西田英毅・本多孝安, 2016：新潟県 西山油帯における油・ガスの移動・集積．石技誌，81 (2)， 159-168.

加藤 進 - 早稲田周 - 西田英毅 - 岩野裕継, 2009 : 新潟県 東頚城地域における泥火山および周辺の原油・ガスの地 球化学. 地学雑誌, 118(3), 455-471.

風早康平，2014:西南日本における温泉水の成因について： スラブ起源深部流体の特徵と分布. 温泉科学, 64 , 282-288.

工藤修治, 1983：1.2 地層流体. 石油鉱業便覧, 23-26.

Kharaka, Y. K. and Mariner, R. H., 1989 : Chemical geothermometers and their application to formation waters from sedimentary basins. Thermal History of Sedimentary Basins. Method and Case Histories (eds. Naeser, N. D. and McCulloh, T. H.), Springer-Verlag, 99-117.

Land, L. S. and Macpherson, G. L., 1992 : Geothermometry from brine analyses: lessons from the Gulf Coast, U.S.A. Applied Geochem., 7, 333-340.
松葉谷治, 1981 : 水素および酸素同位体比からみた温泉水 の起源. 温泉科学, 31(3), 47-56.

松葉谷治, 2009 : 有馬型温泉とはいかなる定義のものか. 温泉科学, 59, 24-35.

Maekawa, T., Igari, S. and Kaneko, N., 2006 : Chemical and isotopic compositions of brines from dissolved-in-water type natural gas fields in Chiba, Japan. Geochem. Jour, 40, 475-484.

村上浩康，2010：リチウム資源. 地質ニュース， 670 号， $22-26$.

Mizota, C and Kusakabe, M., 1994 : Spatial distribution of $\delta \mathrm{D}-\delta{ }^{18} \mathrm{O}$ values of surface and shallow groundwater from Japan, with southern Korea and east China. Geochem. Jour, 28, 387-410.

西尾嘉朗, 2013 ：リチウム同位体による地殼流体研究の新 展開一地殼活動の全貌解明に向けて一. 日本水文科学会 誌, 43(4)，119-135.

野口喜三雄・森崎重喜, 1971 ：油田およびガス田かん水の リチウムおよびヒ素含量とその地球化学的意義. 日本化 学雑誌, 92(2), 145-149.

重川 守, 1985 ：炭素同位体組成による原油と根源岩の対 比一新潟平野油・ガス田地域におけるケーススタディ一. 石技誌，50(1)，9-16.

島津光夫, 2001 : 新潟温泉風土記. 野島出版, $140 \mathrm{p}$.

白石秀一，2005：新潟県における温泉開発の歴史. 新潟応 用地質研究会誌, $63,39-53$.

高橋正明・風早康平・安原正也・塚本 斉・佐藤努 高橋 浩・森川徳敏・大和田道子・尾山洋一・芝原暁 彦・稲村明彦・鈴木秀和 - 半田宙子 - 仲間純子 - 松尾京 子・竹内久子・切田 司・大丸 純, 2011：深層地下水 データベース. 地質調査総合センター研究資料集, no. 532，産業技術総合研究所地質調査総合センター

Takamatsu, N., Imahashi, M., Kamimura, K. and Tsutsumi, M., 1986: Geochemical implication of the lithium content of saline spring waters in Japan. Geochem. Jour, 20, 143-151.

太秦康光 - 那須義和, 1960 ：(第 52 報) 油田塩水と温泉水 の化学成分の比較. 日本化学雑誌, 81 (3), 401-404.

早稲田周・岩野裕継・武田信従, 2002：地球化学からみた 天然ガスの成因と熟成度. 石技誌，67(1)，3-15.

早稲田周・重川 守, 1988 : 本邦油・ガス田地帯における 天然ガスの起源に関する地球化学的考察. 石技誌, 53 (3), 213-222.

渡部直喜 ·大木靖衛 ·佐藤 修 - 日下部実, 1996 : 新潟県 松之山地すべり地の $\mathrm{Na}-\mathrm{Cl}$ 型地下水の起源. 新潟大災害 研年報，18，81-92.

渡部直喜 - 佐藤壽則・古谷 元，2009：新潟地域の大規 模地すべりと異常高圧熱水系. 地学雑誌, 118(3), $543-563$.

藪崎志穂, 2016: 名水を訪ねて (115) 新潟県下越地域の名水. 地下水学会誌, 58(4), 443-459. 